\title{
PERAN DAUN WOKA DALAM MENDUKUNG KEBERLANJUTAN DI KAWASAN EKOWISATA TAPAKULINTANG, SULAWESI UTARA
}

\section{THE ROLE OF WOKA LEAVES IN SUPPORTING SUSTAINABILITY IN TAPAKULINTANG ECOTOURISM AREA, NORTH SULAWESI}

\author{
Tutun Seliari ${ }^{1}$, Fajri Ansari ${ }^{2}$, Fendi Saputra ${ }^{3}$, \\ Fakultas Arsitektur dan Desain UKDW ${ }^{1}$, Balitbang LHK Makassar², \\ Taman Nasional Bogani Nani Wartabone ${ }^{3}$ \\ tutunseliari@staff.ukdw.ac.id ${ }^{1}$
}

\begin{abstract}
ABSTRAK
Woka (Livistona) adalah salah satu jenis tanaman yang tumbuh di Sulawesi Utara, Indonesia. Di Sulawesi Utara, daun woka sering digunakan untuk keperluan kuliner dan sebagai bahan penutup atap. Penggunaan daun woka sebagai sumber daya terbarukan dapat menjadi ide dalam mendukung keberlanjutan di kawasan ekowisata. Studi kasus yang diambil adalah pengembangan Kawasan Wisata Tapakulintang, Molibagu, Bolaang Mangondow Selatan, Sulawesi Utara. Wilayah Tapakulintang yang sebagian besar berupa hutan berada di zona penyangga Taman Nasional Bogani Nani Wartabone. Daya tarik utama di daerah Tapakulintang adalah wisata pengamatan burung, pembuatan gula merah, mengambil madu hutan, dan penetasan telur Maleo yang dikelola oleh masyarakat. Saat ini, Kawasan Wisata Tapakulintang sedang dikembangkan menjadi kawasan ekowisata. Metode yang digunakan dalam penelitian ini adalah grounded research. Penelitian yang membumi digunakan untuk menentukan penggunaan daun Woka oleh masyarakat. Studi ini berfokus pada keterampilan masyarakat dalam menganyam daun Woka menjadi bahan penutup atap dan dinding, serta bungkus makanan. Salah satu keterampilan masyarakat ini perlu dipertahankan dengan menerapkan daun woka sebagai elemen arsitektural dalam desain pengembangan kawasan Tapakulintang. Penggunaan daun woka sebagai pembungkus makanan juga merupakan bagian dari penggunaan bahan ramah lingkungan di kawasan Tapakulintang.
\end{abstract}

Kata kunci: ekowisata, keberlanjutan hutan, keterampilan masyarakat, daun woka, material alam

\section{ABSTRACT}

Woka (Livistona) is one type of plant that grows in North Sulawesi, Indonesia. In North Sulawesi, Woka leaves are often used for culinary use and as roof cover material. The use of Woka leaves as a renewable resource can be an idea in supporting sustainability in an ecotourism area. The case study taken was the development of the Tapakulintang Tourism Area, Molibagu, Bolaang South Mangondow, North Sulawesi. The Tapakulintang area which is mostly in the form of the forest is in the buffer zone of Bogani Nani Wartabone National Park. The main attraction in the Tapakulintang area is bird watching, besides that it is a community activity for making brown sugar, taking forest honey, and Maleo egg hatching managed by the community. Currently, the Tapakulintang Tourism Area is being developed into an ecotourism area. The method used in this study is grounded research. Grounded research is used to determine the use of Woka leaves by the community. This study focuses on people's skills in weaving Woka leaves into roof and wall covering materials, as well as a food wrapping. One of these community skills needs to be preserved by applying Woka leaves as an architectural element in the design of the development of the Tapakulintang area. The use of Woka leaves as a food wrap is also part of the use of environmentally friendly materials in the Tapakulintang area.

Keyword : ecotourism, sustainability forest, community skill, Woka leaves, environmentally material 


\section{Research Fair Unisri 2019}

Vol 4, Number 1, Januari 2020

PENDAHULUAN

Kawasan Wisata Tapakulintang (KWT) merupakan sebuah kawasan wisata yang berada di wilayah Taman Nasional Bogani Nani Wartabone (TNBNW) Sulawesi Utara. KWT berada di zona pemanfaatan yang pengelolaannya dalam kewenangan dan tanggung jawab Resort Pantai Selatan, Seksi Pengelolaan Taman Nasional Wilayah II Doloduo. KWT mengangkat tema wisata sebagai areal birdwatching, disamping adanya atraksi wisata berupa aktivitas keseharian dan budaya lokal masyarakat sekitar di kawasan hutan Batu Menangis. Berdasarkan administrasi pemerintahan, kawasan ini berada dalam wilayah pemerintahan Desa Molibagu, Kecamatan Bolaang Uki, Kabupaten Bolaang Mongondow Selatan. Selain memiliki kekayaan keragaman hayati flora dan fauna yang cukup tinggi, KWT juga memiliki beragam potensi keindahan alam yang jika digarap dengan baik akan sangat mendukung untuk dikembangkan menjadi destinasi wisata baru, seperti sungai Tapakulintang, dan bendungan, yang memiliki panorama alam yang indah, dan sumber air panas. Areal KWT juga memiliki kelebihan lain yang dapat dikembangkan menjadi daya tarik wisata, yaitu adanya aktivitas tradisional masyarakat lokal yang menarik untuk disaksikan, seperti atraksi pembuatan gula merah dan pengambilan madu dari hutan, dan habitat peneluran Maleo yang dikembangkan oleh komunitas dampingan TNBNW. Atraksi yang berada di dalam hutan tersebut dapat dicapai dengan menyusuri jalan setapak yang masih berupa jalur rintisan.

Pengembangan KWT menjadi sebuah kawasan ekowisata sangat perlu dilakukan mengingat kawasan tersebut berada di kawasan

\section{P- ISSN: 2550-0171 \\ E- ISSN: 2580-5819}

penyangga TNBNW. Ekowisata mengusung konsep pariwisata yang berkelanjutan. Menurut The International Ecotourism Society (2015) (TIES), ecotourism (ekowisata) merupakan suatu bentuk perjalanan secara bertanggungjawab ke area alami dengan cara menjaga kelestarian lingkungan, membantu meningkatkan kesejahteraan masyakat sekitar dan melibatkan unsur interpetasi dan pendidikan terutama terhadap pengelola dan pengunjung. Tren pariwisata global yang mulai beralih ke 'green tourism' memberi peluang bagi KWT untuk menjadi sebuah destinasi minat khusus yang sangat menarik untuk dikunjungi. Prinsip ekowisata dirasa merupakan sebuah konsep yang tepat untuk diangkat menjadi konsep pengembangan di KWT. Eksplorasi potensi dan pengembangan secara bertanggungjawab sangat diperlukan mengingat saat ini potensi yang ada di KWT belum dikemas secara maksimal. PEngembangan kawasan KWT ini juga berdasarkan dari salah satu tujuan dari Sustainable Development Goals (SDGs) yaitu 'life on land' yang menjaga kehidupan yang seimbang dan selaras dengan lingkungan alam.

Salah satu potensi utama di area KWT adalah daun woka. Palem serdang (Livistona rotundifolia) atau dalam bahasa lokal disebut woka merupakan jenis palem dengan tajuk berbentuk bundar dan daun mudanya banyak digunakan oleh masyarakat sebagai pembungkus nasi. Selain sebagai pembungkus nasi kuning, daun woka muda juga dimanfaatkan sebagai bahan pembukus kue dodol khas Sulawesi Utara. Woka banyak digunakan sebagai pembungkus karena permukaannya licin, mulus dan anti lengket. Umumnya woka digunakan sebagai pembungkus 
Research Fair Unisri 2019

Vol 4, Number 1, Januari 2020

makanan tradisional, wadah tradisional, pembungkus hasil kebun dan buruan, atap dan dinding rumah, tanaman hias serta untuk penguburan tradisional suku minahasa kuno. Pada daerah pedesaan masih dapat ditemukan rumahrumah yang menggunakan daun woka baik sebagai atap ataupun untuk dinding. Maka tidaklah mengherankan jika pada ladang atau kebunkebun masyarakat banyak ditemukan gubuk kerja (daseng) yang sebagian besar bahan bakunya berasal dari daun woka. (Nurrani, 2013). Menurut Mogea(1992) dalam Rahayuh dan Rugayah (2010), di Sulawesi Utara, daun woka digunakan sebagai atap dan tangkai daunnya untuk dinding rumah. Hal ini terbukti juga di dalam area KWT terdapat rumah pengolahan gula aren yang atapnya menggunakan daun woka. Begitu juga untuk kandang habitat peneluran maleo juga dibuat oleh komunitas menggunakan atap dari daun woka. Bagi masyarakat di Sulawesi Utara daun woka biasa digunakan membuat atap untuk rumah kebun. Berdasarkan Pornalingo (2015) pengetahuan masyarakat tentang alam, tumbuhtumbuhan dan binatang sangat erat hubungannya dengan kehidupan sehari-harinya.

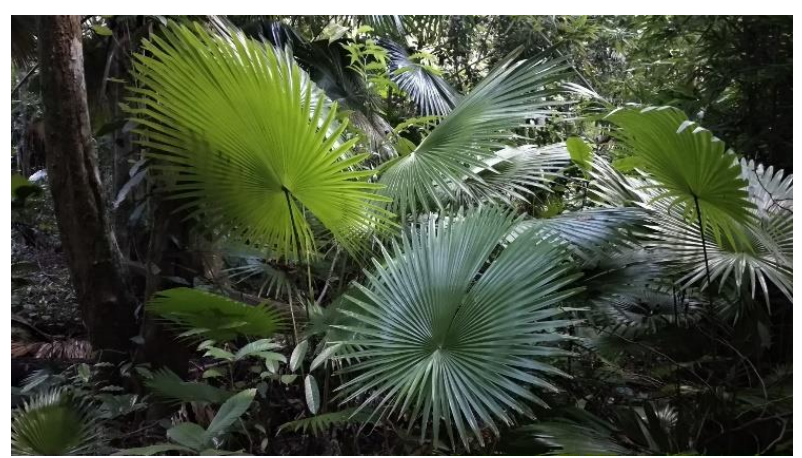

Gambar 1. Daun Woka di Kawasan Tapakulintang

Sumber : Dokumentasi Penulis (2018)
P- ISSN: 2550-0171

E- ISSN: 2580-5819

Kehidupan masyarakat di sekitar area KWT juga sangat menarik untuk digali, karena masyarakat tersebut juga memanfaatkan hutan untuk keberlangsungan kehidupannya. Terciptanya hubungan yang harmonis antara hutan dan masyarakat perlu diwujudkan untuk menjaga kelestarian alam. Perlakuan masyarakat dalam memanfaatkan bahan alam bagi keberlangsungan hidupnya juga dapat dikemas menjadi sebuah daya tarik / atraksi, salah satunya adalah tentang ilmu ketukangan. Dalam Fauziah dan Sulistijowati (2016), ketukangan merupakan suatu keahlian yang terbentuk dari kearifan lokal yang diturunkan dari generasi ke generasi. Material lokal adalah salah satu kekayaan alam yang melimpah namun malah mulai kehilangan eksistensinya di negeri sendiri.

Berdasarkan uraian di atas, didapatkan rumusan permasalahan bagaimana eksplorasi ilmu ketukangan dan pemanfaatan material alam yang terbarukan oleh masyarakat di area KWT sangat perlu dilakukan untuk menjaga eksistensinya dan hubungannya dengan keharmonisan alam. Hal tersebut juga merupakan sebuah keunikan yang mungkin tidak ditemukan di daerah lain sehingga dapat dijadikan sebagai identitas bagi pengembangan area KWT menjadi kawasan ekowisata. Secara spesifik dengan eksplorasi peran daun woka sebagai material ramah lingkungan dalam menjaga keberlanjutan di area KWT. Pengenalan keterampilan, ilmu ketukangan, cara hidup masyarakat, dan kearifan lokal menjadi suatu hal yang menarik sehingga terjadi pembelajaran antara masyarakat pengelola dan pengunjung di area KWT. 


\section{Research Fair Unisri 2019 \\ Vol 4, Number 1, Januari 2020}

\section{BAHAN DAN METODE}

Penelitian ini merupakan kajian yang bersifat grounded research. Menurut Locke, 2003 dalam dokumen Feasibility Study Kawasan Wisata Tapakulintang grounded research merupakan kajian yang tidak mengutamakan teori, tetapi analisis dari kajian ini lebih menekankan pada peran penting data yang dikumpulkan di lapangan. Dalam kajian yang bersifat grounded research ini, digunakan beberapa metode pengumpulan data, yaitu metode survey, observasi, dan wawancara serta pengukuran lapangan. Penelitian ini mengkaji dan eksplorasi keterampilan masyarakat dalam memanfaatkan daun woka yang tidak hanya digunakan sebagai bahan bangunan ataupun elemen arsitektural di dalam kawasan namun pemanfaatannya dalam bidang lain dan kemungkinan untuk pengembangannya. Pengembangan material woka yang dapat dimanfaatkan menjadi industri kreatif sehingga bisa meningkatkan perekonomian masyarakat. Penggunaan material ramah lingkungan ini dapat menjaga eksistensi dan keberlanjutan dari kawasan KWT.

\section{HASIL DAN DISKUSI}

Potensi atraksi area KWT sangat erat kaitannya dengan potensi alam yang perlu untuk dikemas menjadi daya tarik yang menarik. Selain birdwatching potensi utama yang dikembangkan masyarakat sekaligus konservasi alam di KWT adalah habitat peneluran Maleo yang dikembangkan komunitas dampingan TNBNW. Untuk mengunjungi habitat peneluran Maleo di area KWT merupakan perjalanan yang cukup menantang dengan menyusuri perbukitan di kawasan penyangga TNBNW, melalui sungai,

\section{P- ISSN: 2550-0171 \\ E- ISSN: 2580-5819}

bendungan dan menyusuri hutan melalui jalan rintisan setapak.

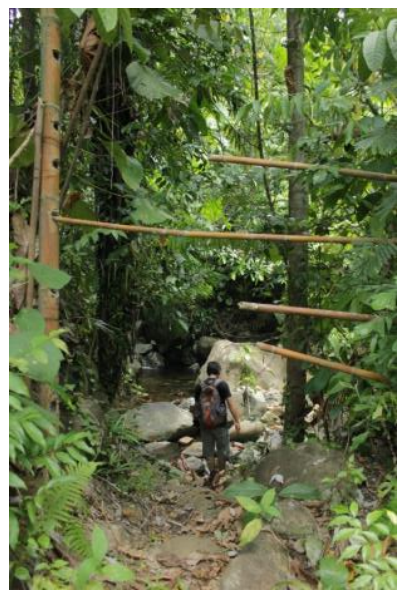

Gambar 2. Akses menuju habitat peneluran Maleo Sumber : Dokumentasi Penulis (2018)

Habitat peneluran Maleo ini dikelola oleh komunitas Modaga No Suwangge kelompok Tani MMP TNBNW. Inisiatif pengelolaan habitat peneluran Maleo ini adalah dari masyarakat yang mendapat dukungan penuh dari TNBNW. Saat ini

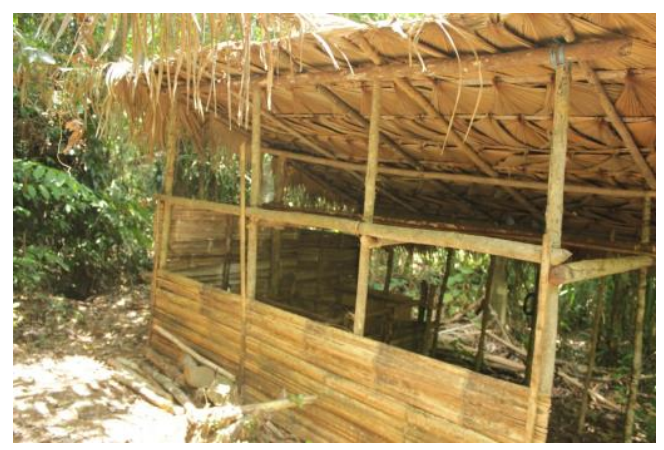

di area peneluran Maleo ini baru terdapat fasilitas kandang yang digunakan untuk peneluran Maleo.

Gambar 3. Kandang habitat peneluran maleo

Sumber : Dokumentasi Penulis (2018)

Kandang tersebut dibangun oleh masyarakat dengan menggunakan material yang ada disekitar menggunakan kayu, papan kayu, dan atap dari daun woka. Hal yang menarik disini adalah berupa 
Research Fair Unisri 2019

Vol 4, Number 1, Januari 2020

keterampilan ketukangan maysarakat dalam menyusun daun woka menjadi atap. Jika diperhatikan secara detail, cara pasang susunan daun woka terhadap reng struktur atap tersebut menimbulkan estetika yang sangat menarik. Tangkai dari daun woka diselipkan pda reng atap dengan posisi daun berada di bawah reng, dan saling overlapping dengan susunan atap di atasnya untuk mencegah tampias air hujan.

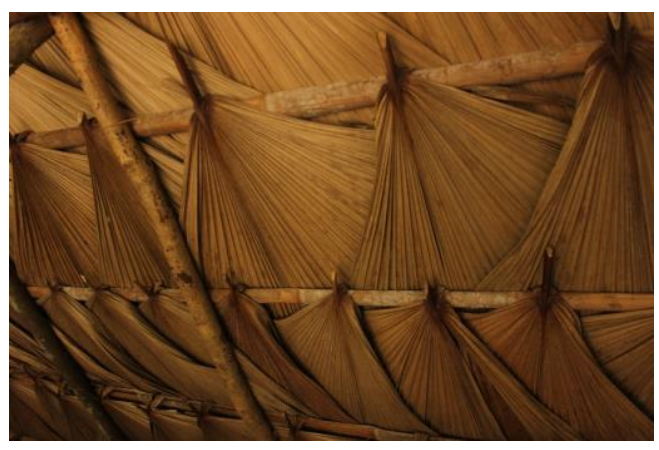

Gambar 4. Susunan daun woka sebagai atap Sumber : Dokumentasi Penulis (2018)

Hal ini menjadi sebuah daya tarik ketrampilan masyarakat yang memanfaatkan sumber daya sekitar bisa dijadikan elemen arsitektural tidak hanya mempertimbangkan fungsi saja tetapi juga estetika. Keterampilan masyarakat ini dapat dijadikan sebagai penguatan daya Tarik bagi area KWT. Selain di area habitat peneluran Maleo, berdekatan dengan area tersebut terdapat sebuah bangunan yang dibangun dan digunakan masyarakat sebagai pondok untuk pengolahan gula aren. Pondok tersebut berada di tengah hutan dan berada di tepi sungai yang mengalir di kawasan hutan. Pondok pengolahan gula aren tersebut juga menggunakan material yang ramah lingkungan antara lain kayu, bambu, papan dan penutup atap dari daun woka. Walaupun sama-sama menggunapak penutup atap daun woka, namun
P- ISSN: 2550-0171

E- ISSN: 2580-5819

berbeda cara susunannya dengan atap yang digunakan untuk kandang peneluran Maleo.

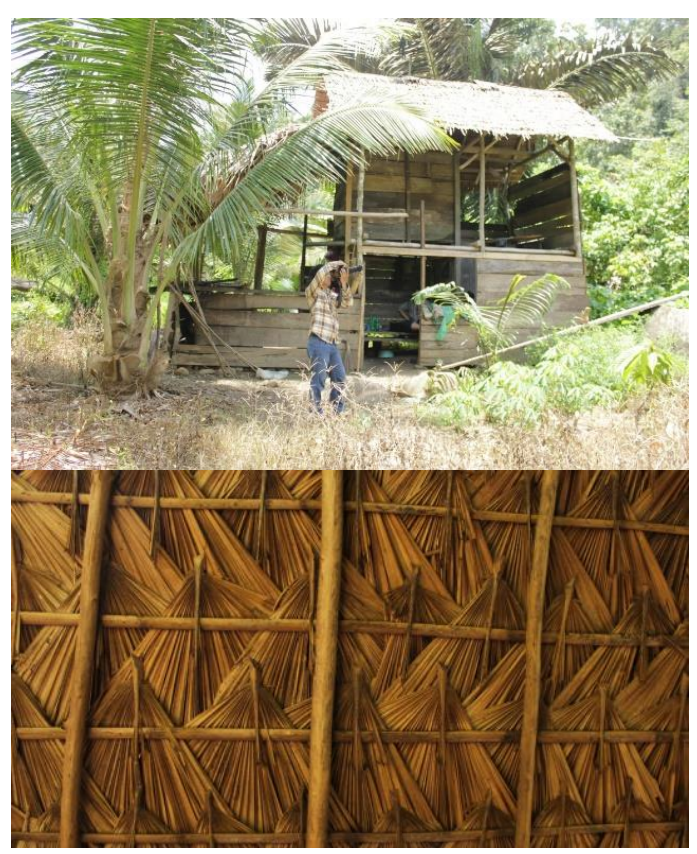

Gambar 5. Pondok pengolahan gula aren Sumber : Dokumentasi Penulis (2018)

Cara menyusun daun woka pada atap pondok pengolahan gula aren, tangkai daun woka diselipkan pada reng, daun woka berada di atas reng. Ragam keterampilan masyarakat ini sangat manarik untuk dikembangkan menjadi keberagaman keterampilan yang perlu didokumentasikan untuk eksistensi dan keberlanjutan di area KWT. Keterampilan masyarakat dalam menyusun dan merangkai daun woka menjadi sebuah elemen arsitektural ini dapat dikembangkan menjadi daya tarik dan identitas bagi kawasan, bahkan tidak hanya sebagai atap saja tetapi juga dapat dimanfaatkan sebagai dinding ataupun elemen arsitektural yang lain 
Research Fair Unisri 2019

Vol 4, Number 1, Januari 2020

dalam pengembangan fasilitas di kawasan KWT menjadi kawasan ekowisata. Terlebih lagi tanaman woka dapat dibudidayakan dan ramah lingkungan.

Isu strategis pada area KWT tidak hanya berupa eksplorasi potensi saja. Kunjungan ke Tapakulintang mulai meningkat terutama wisatawan mancanegara dan para peneliti. Wisatawan yang datang pun lebih pada wisatawan yang mempunyai minat khusus. Hal ini memerlukan daya dukung bagi KWT sebagai sebuah destinasi sehingga perlu direncanakan dengan baik. Penguatan daya tarik dan fasilitas pendukung sangat perlu dilakukan, Pemanfaantan daun woka merupakan salah satu hal yang dapat dilakukan untuk memperkuat identitas kawasan KWT, yang dapat diterapkan terhadap fasilitasfasilitas dan daya dukung nya.

Pengembangan area KWT sebagai destinasi wisata dengan konsep ekowisata minat khusus (Hutan dan Ekologi) merupakan hubungan dari ketiga aspek yang saling berkaitan yaitu konservasi, wisata dan edukasi.

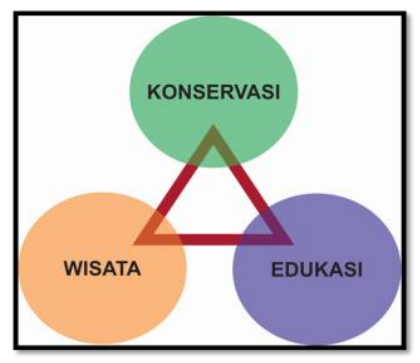

Gambar 6. Konsep Pengembangan Ekowisata di KWT Sumber : Dokumentasi Penulis (2019)

Aspek konservasi menjadi bagian yang sangat penting karena lokasi KWT yang berada di kawasan penyangga Taman Nasional Bogani Nani

\section{P- ISSN: 2550-0171 \\ E- ISSN: 2580-5819}

Wartabone dan didalamnya terdapat flora fauna endemik. Aspek wisata tidak bisa lepas dari aspek konservasi dan edukasi sebagai bentuk kegiatan pariwisata yang bertanggung jawab terhadap lingkungan alam. Peran daun woka terhadap keberlanjutan KWT memerlukan eksplorasi dan pengembangan menjadi bagian yang mendukung terhadap proses kegiatan pariwisata yang berlangsung di KWT. Pengembangan daun woka sebagai bentuk dari konservasi kekayaan alam dan edukasi pengetahuan kepada masyarakat/ pengunjung tentang manfaat dari material ramah lingkungan. Berdasarkan penelitian, pengembangan daun woka dapat diklasifikasikan dalam 2 hal, yaitu yang pertama elemen arsitektural dan yang kedua industri kreatif. Sebagai elemen arsitektural daun woka dapat dimanfaatkan dalam rancangan fasilitas pendukung di KWT antara lain sebagai penutup atap dan dapat dikembangkan menjadi material dinding atau partisi. Dalam hal industri kreatif daun woka dapat dimanfaatkan sebagai pembungkus makanan, misal nya pembungkus gula aren yang menjadi atraksi yang di KWT. Daun woka juga dapat dikembangkan menjadi produk sebagai alat saji makanan sehingga lebih ramah lingkungan dan mengurangi penggunaan plastik.

Sebagai langkah untuk pengembangan KWT menjadi kawasan ekowisata yang berkelanjutan diperlukan strategi untuk mencapai hal tersebut. Strategi pengembangannya adalah dengan melakukan gerakan stop plastik di area KWT, budidaya dan pemanfaatan material alam (woka) sebagai identitas kawasan, penyususnan guideline pengembangan ekowisata dalam mendukung keberlanjutan di KWT (kawasan TNBNW), 
Research Fair Unisri 2019

Vol 4, Number 1, Januari 2020

melakukan pendampingan terhadap komunitas masyarakat di kawasan penyangga, pengembangan industri kreatif - material dan keterampilan lokal, dan pengembangan yang memperhatikan aspek arsitektur ekologi dan ketukangan lokal.

\section{KESIMPULAN}

Daun woka yang merupakan material ramah lingkungan sebagai potensi di area KWT memerlukan eksplorasi dan pengembangan dalam pemanfaatannya untuk mendukung keberlanjutan di area KWT sebagai destinasi ekowisata minat khusus. Keterampilan masyarakat lokal di sekitar dalam mengolah dan memanfaatkan daun woka dalam kehidupan kesehariaanya menjadi identitas kawasan yang dapat menjadi daya tarik bagi pengembangan KWT. Eksplorasi sangat diperlukan terutama dalam hal pamanfaatan daun woka sebagai elemen arsitektural dan industri kreatif yang menjadi bagian dari pengembangan fasilitas pendukung wisata di KWT. Keberlanjutan disini tidak hanya keberlanjutan dalam hal lingkungan alam dengan budidaya woka tetapi juga keberlanjutan dari sumberdaya manusia sebagai aktor yang berperan aktif mengelola keberlanjutan di kawasan KWT. Sinergi antar stakeholder dari pihak masyarakat, Taman Nasional, Pemerintah Daerah, LSM atau NGO yang mendampingi, akademisi, swasta dan seluruh pihak terkait sangat diperlukan untuk berkolaborasi mewujudkan KWT sebagai destinasi ekowisata yang bertanggungjawab terhadap keberlanjutan lingkungan.

DAFTAR PUSTAKA/RUJUKAN

Fauziah, N. dan Sulistijowati, M. 2016. Pendekatan Ekologis dan Tektonika Bahan Pada Perancangan Galeri Seni Ketukangan
P- ISSN: 2550-0171

E- ISSN: 2580-5819

Jurnal Sains dan Seni ITS. Vol. 5, No.2, Hal G.303-307.

Pomalingo, S. 2015. Polahi: Komunitas Pedalaman Suku Gorontalo. Cultura: Jurnal Dinamika Sosial dan Budaya 1, hal. 53-62

Nurrani, L. 2013. Pemanfaatan Tradisional Tumbuhan Alam Berkhasiat Obat Oleh Masyarakat Di Sekitar Cagar Alam Tangale. Info BPK Manado Volume 3 No 1, hal 1-22.

Rahayu, M., dan Rugayah. 2010. Masyarakat Lokal Pulau Kabaena- Sulawesi Tenggara / Local knowledge and Plant Utilization by Local People of Kabaena Island Southeast Celebes. Berita Biologi - Jurnal ilmu-Ilmu Hayati. Vol 10, No 1, hal 67-75

Dokumen FS Kawasan Wisata Tapakulintang. 2018. Taman Nasional Bogani Nani Wartabone.

The International Ecotourism Society. (2015). TIES Announces Ecotourism Principles Revision [Press release]. Retrieved from http://www.ecotourism.org/news/tiesannounces-ecotourism-principles-revision 